\title{
Spatiotemporal variation of roadkills show mass mortality events for amphibians in a highly trafficked road adjacent to a national park, Costa Rica
}

\author{
J. Edgardo Arévalo ${ }^{1,2^{*}}$, Wataru Honda ${ }^{3}$, Adrián Arce-Arias ${ }^{4}$ \& Achim Häger ${ }^{1}$ \\ 1. The School for Field Studies, Apartado postal 150-4013, Atenas, Alajuela, Costa Rica; earevalo@fieldstudies.org, \\ ahaeger@fieldstudies.org \\ 2. Escuela de Biología, Universidad de Costa Rica, San Pedro Montes de Oca, San José, Costa Rica. \\ 3. Japan International Cooperation Agency, Global Environment Department Forestry and Nature Conservation Group; \\ Honda.Wataru@jica.go.jp \\ 4. Sistema Nacional de Areas de Conservación - Area de Conservación Pacífico Central; adrian.arce@sinac.go.cr \\ * Correspondence
}

Received 23-V-2017. Corrected 28-VII-2017. Accepted 29-VIII-2017.

\begin{abstract}
Roads have detrimental impacts on wildlife populations around the world. Specifically, roads pose direct and indirect threats to wildlife by limiting dispersal movements or through vehicle-related mortality. The rate of wildlife mortality varies both in time and space depending on the landscape composition and the type and use of road infrastructure. The objective of this study was to investigate spatiotemporal variation of vertebrate mortality in a $4 \mathrm{~km}$ segment of the 34 national road, adjacent to Carara National Park, Costa Rica. We conducted 81 roadkill surveys by car and bicycle from June 2010 to May 2011, georeferenced the locations of the kills and identified them to the lowest possible taxonomic level. We recorded a total of 4709 road-killed animals of at least 58 species of vertebrates during the whole study. Amphibians accounted for $93.5 \%$ of all the vertebrate losses and showed strong spatiotemporal variation of mass mortality events. Reptiles, especially snakes, were the second most affected taxon followed by mammals and birds. Relative mortality per day in the $4 \mathrm{~km}$ segment was 125.4 amphibians, 4.6 reptiles, 2.7 mammals, 1 bird and 0.46 undetermined. Road proximity to the border of the park, traffic volumes and lack of enforcement of speed limits may influence the high rate of roadkills found. We suggest the reinforcement of speed limits, wildlife crossing signage and the retrofitting of the existing culverts as under passes for animals to minimize vertebrate mortality at the road adjacent to Carara National Park. Rev. Biol. Trop. 65 (4): 1261-1276. Epub 2017 December 01.
\end{abstract}

Key words: amphibian mass-kill, animal-vehicle collisions, conservation areas, extinction threat, tropical forest.

Road networks are human extensions that facilitate transportation and economic development. However, the construction and the use of roads generate a broad range of negative effects, including habitat loss, fragmentation, the emissions of chemicals and noise pollution (reviews in Forman et al., 2003; Coffin, 2007; Van der Ree, Smith, \& Grilo, 2015). Furthermore, roads may limit or preclude animal dispersal (e.g. Mader, Schell, \& Kornacker, 1990; Clarke, White, \& Harris, 1998; Develey \& Stouffer 2001; Colchero et al., 2010; Long,
Diefenbach, Wallingford, \& Rosenberry, 2010) and induce mortality through vehicle-animal collisions (reviews in Forman \& Alexander, 1998; Forman et al., 2003; Coffin, 2007; Van der Ree et al., 2015).

Although the road-automobile system is a relatively recent source of wildlife mortality, it accounts for millions of roadkills every year in different latitudes, and may well exceed natural mortality rates in certain populations (Forman \& Alexander, 1998). Indeed, researchers have generated some remarkably high historical 
estimates of yearly roadkill, such as 2.5 million birds in Britain (Hodson \& Snow, 1965), 5.48 million frogs and reptiles in Australia (Ehmann \& Cogger, 1985; cited in Forman et al., 2003), 1.2 million deer (Odocoileus virginianus and O. hemionus) (Bissonette, 2002) and 80 million birds (Erickson, Johnson, \& Young Jr., 2005) in the United States. These numbers illustrate the magnitude of this human induced phenomenon.

The frequency at which animals of different taxonomic groups are reported to be killed on roads varies greatly. After reviewing several early roadkill studies conducted during the twentieth century, Forman et al. (2003) concluded that birds and mammals were the most affected taxa, with much fewer reports of amphibians and reptiles. The authors suggested that the apparent underrepresentation of amphibians might be due to their (typically) small size and the associated rapid carcass removal by scavengers. Small body size animals are less likely to be detected during roadkill surveys and disappear from roads faster that large body size species (Slater, 2002; Ford \& Fahrig, 2007; Barthelmess \& Brooks, 2010; Guinard, Julliard, \& Barbraud, 2012; Teixeira, Coelho, Esperandio, \& Kindel, 2013). In addition, surveys conducted by cars are more likely to miss small animals than those conducted by foot or bicycles, particularly along verges (Langen et al., 2007; Guinard et al., 2012). For instance, in a four year roadkill survey conducted near Lake Eire in Canada, Ashley and Robinson (1996) found that $92.1 \%$ from 32000 roadkills were amphibian, followed by birds (4.3 $\%)$, reptiles $(2.7 \%)$ and mammals $(0.9 \%)$. In this study, the high numbers of amphibian deaths along the $3.2 \mathrm{~km}$ road segment can be attributed the existence of a large wetland and the slow detailed search by foot and bicycle. However, González-Gallina, Benítez-Badillo, Rojas-Soto and Hidalgo-Mihart (2013) found that mammals were the most frequently killed on roads in grassland in Mexico, and that $95 \%$ of the 827 mammals found were small rodents. In addition, accurate accounts and precise identification of small bodies were achieved recently using DNA barcoding in Brazil
(Rodríguez-Castro, Ciocheti, Ribeiro, Ribeiro, \& Galetti Jr., 2017).

Although roadkills are commonly reported as an average number per $\mathrm{km}$, dead animals are not distributed evenly along the roads. Brockie (2007) found that a disproportionate number of possums (Trichosurus vulpecula) and hedgehogs (Erinaceus europaeus) were killed in or near bridges in New Zealand, a spatially aggregated pattern that the author termed roadkill "blackspots". Patterns of spatial distribution of roadkills are often associated with animal aggregations around critical resources such as spawning sites and migratory routes in amphibians (Elzanowski, Ciesiolkiewicz, Kaczor, Radwanska, \& Urban, 2009), as well as with food resources along and/or near roads (Forman \& Alexander, 1998; Coffin 2007). Another important factor that may determine roadkill frequency is seasonality. Some mammal species are killed in higher numbers during their breeding season (Groot-Bruinderink \& Hazebroek, 1996; Clevenger, Chruszcz, \& Gunson, 2003). Seasonal differences in mortality rate were also observed for tropical bird species in two federal highways in Southern Brazil (Alvez da Rosa \& Bager, 2012). In addition, the spatial configurations and attributes of roads within landscapes and their distance to wildlife habitats may influence the rate at which animals are killed (Glista, DeVault, \& DeWoody, 2008; Fahrig \& Rytwinski 2009; Rodríguez-Castro et al., 2017). Thus, roads in close proximity to natural habitats are expected to have greater impacts on wildlife than those located away from natural habitats. This is because deforested or altered landscapes typically have less species and lower animal densities than natural habitats.

Knowledge of roadkill dynamics has contributed to mitigation actions to minimize wildlife mortality in many developed countries. However, there have been relatively few studies on roadkill incidence in tropical habitat countries. A review by Taylor and Goldingay (2010) on roadkill studies around the world showed a strong bias towards temperate zones. The authors found that $51 \%$ of studies were 
conducted in North America, $25 \%$ in Europe, $17 \%$ in Australia and only $7 \%$ in other countries (Coelho, Kindel, \& Coelho, 2008; Cáceres et al., 2010; González-Gallina et al., 2013; Rodríguez-Castro et al., 2017). Such a distinct geographical bias is holding back the development of effective conservation policy in the tropics, where large expanses of pristine tropical rain forest are being subjected to road construction (Laurance, Goosem, \& Laurance, 2009). Thus, baseline research on the assessments of wildlife populations and direct animal mortality due to collision with vehicles is needed to effectively mitigate the negative effects of roads.

Although mortality of wildlife in Costa Rican roads is considered a conservation issue, very few published studies on this subject are available (Monge-Nájera, 1996; Rojas-Chacón, 2011; Pomareda, 2012). The objective of this study was to document rates of vertebrate mortality along the National Road 34, adjacent to Carara National Park in Costa Rica. We examined the temporal and spatial variation of roadkill patterns for the different taxonomic groups to identify potential "blackspots" (sensu Brockie, 2007) and review current mechanisms that help to minimize roadkill events. Finally, we propose concrete short-term actions to reduce the rate of roadkills near protected areas utilizing Carara National park case study.

\section{MATERIALS AND METHODS}

Study site: The study was conducted in a $4 \mathrm{~km}$ segment of the National Road 34 (known as the Costanera Sur), an extensive road of $202 \mathrm{~km}$ total that limits the national park $\left(9^{\circ} 47^{\prime} 56.21^{\prime \prime} \mathrm{N}-84^{\circ} 36^{\prime} 17.35^{\prime \prime} \mathrm{W} \&\right.$ $9^{\circ} 46^{\prime} 1.57^{\prime \prime} \mathrm{N}-84^{\circ} 36^{\prime} 43.52^{\prime \prime} \mathrm{W}$, Fig. 1). The road was built in 1973 and consists of a two lane $9 \mathrm{~m}$ wide paved road with vehicles circulating in both directions. There are no hard shoulders and the road is separated from the forest edge by a strip of $7.6 \pm 5.2 \mathrm{~m}$ (average \pm s.d.) that is covered with grassy vegetation. Extensive mature forest is found on the national park side, whereas pasture with small forest fragments and trees planted in rows predominate on the other side of the road (Fig. 1).

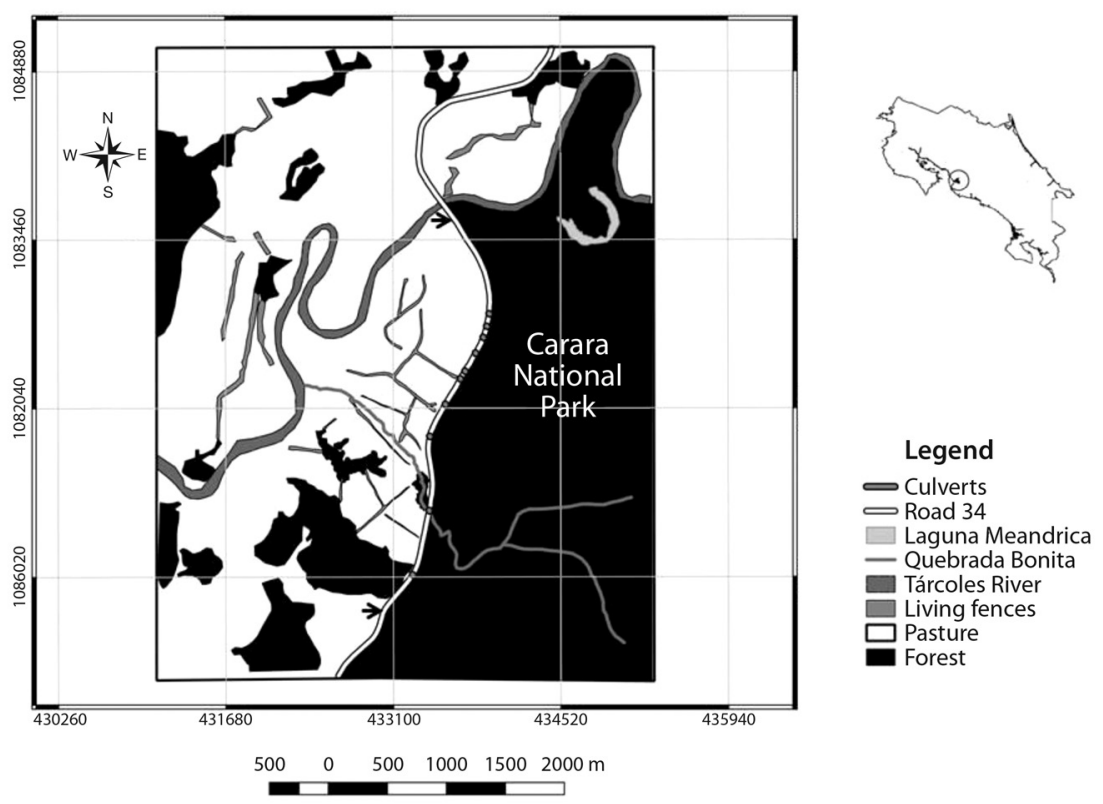

Fig. 1. Study area showing the landscape composition adjacent to Carara National Park. The two arrows delimit the segment of the surveyed road. Culverts under the road vary in size and shape. The largest is a $3 \times 2.5 \mathrm{~m}$ underpass that is crossed by Quebrada Bonita. The other culvers range between 0.6 to $1.50 \mathrm{~m}$ in diameter. 
Carara National Park is 5242 ha in size and ranges in elevation from 20 to 492 m.a.s.l. The main study area is in the lowest elevation and is located within the tropical premontane moist forest basal belt transition (Holdridge, 1966). This forest remnant is the largest mature wetto-dry transitional forest in the country, with an average temperature of $27{ }^{\circ} \mathrm{C}$ and receives an average of $2800 \mathrm{~mm}$ per year (mainly in the rainy season from May through December).

Methods: We used a car (13 surveys) and a bicycle (22 surveys) to conduct vertebrate roadkill surveys from June 2010 to May 2011. In the first five months, park rangers accompanied by one of the authors (WH) conducted the counts by slowly driving a car $(20-30 \mathrm{~km} /$ hour $)$ along the road in both lanes ("U" shape circuit). From mid-December to May 2011, WH used a bicycle to detect and record the roadkills, and took the coordinates (Garmin GPSMAP $60 \mathrm{CSx}$ ) and photographs of each dead animal. If species identification was impossible, the animal was identified to the lowest possible taxonomic category. A small number $(0.34 \%)$ of animals were placed in the "undetermined" category. Dead animals were removed from the road and points of mass kills (hundreds) of amphibians were noted to avoid double counts. In the case of mass kill events, we estimated the number of kills by counting individuals within a smaller area (approximately $5 \times 5$ meters) and then extrapolating to the space covered by most of the dead animals. Many of the amphibian bodies were fragmented and scattered across the road. Thus, we kept our estimates as conservative as possible by counting the evident animals to minimize the overestimation.

We conducted an average of 3.5 (2-5) regular systematic counts per month and other additional counts depending on time availability and in response to roadkill reports by local tourist guides or park rangers. We conducted regular counts on Mondays from 8:00 to 10:00 a.m. whereas other additional counts varied in days and time sampling efforts. We carried out 35 regular surveys and 46 opportunistic ones for a total of 81 roadkill surveys during the study period. Since the number of regular surveys per month and the additional opportunistic counts varied in search time effort, we used only the regular surveys to assess spatiotemporal variation in vertebrate road mortality (August 2010-May 2011). Thus, relative mortality is based on the number of roadkills divided by the number of days for the regular counts.

We analyzed the spatial distribution of the recorded roadkills using a quartic kernel shape function in the 'Heatmap' plug-in for QGIS 2.1.16.0 (QGIS Developing Team 2016). Kernel functions calculate the density probability of point features within a smoothed surface area (Silverman, 1986). To optimize the visual presentation of spatial roadkill variation, the search radius for generating kernel density surfaces was set at $50 \mathrm{~m}$ around each dead individual. Point density is calculated by adding the values of all overlapping kernel surfaces within any cell of a determined size. Output cell size was set at $1 \times 1 \mathrm{~m}$. As the distribution of dead amphibians was very strongly clumped (over-representation of high density values), density classes were divided into quantiles, in order to show the entire range of the density distribution on the map. For all other taxonomic groups, density values were classified by equal intervals.

To determine traffic volumes in the surveyed road we conducted 43 one hour counts in different days of the week. The counts took place between 1:00 and 4:00 p.m. and we tallied light (cars and small vans) and heavy vehicles (buses, large trucks and trailers) using two manual counters. In addition, we compared average traffic volumes between weekdays (Monday-Thursday) and weekends (FridaySundays) using the Wilcoxon test.

\section{RESULTS}

We recorded 4709 roadkills, which were represented by 58 species, when the regular and opportunistic surveys were combined. From this total, 4402 remains were amphibians accounting for $93.5 \%$ of all vertebrate losses. The second most affected group was reptiles 
with 160 animals (3.4\%), followed by mammals (96 individuals: $2.0 \%$ ), birds (35 individuals: $0.74 \%$ ) and the undetermined group (16 undetermined body parts: $0.34 \%$ ). Despite the bad condition of many of the animal remains, we were able to identify most $(85.3 \%)$ of the animals to species level. Three species of tree frogs and two species of toads were the most abundant among the amphibians (Table 1). The species Trachycephalus typhonius represented almost half of all species of frogs and toads $(47.7 \%)$. Snakes were the most frequently reptile recorded $(68.1 \%)$. In the case of mammals, unidentified species of mice, rats and bats made the most numerous deaths (Table 1). The Northern Tamandua (Tamandua mexicana) represented $30.8 \%$ of all mammals when rodents and bats are excluded (Table 1). No particular species dominated the numbers of roadkills for the avian group (Table 1).

TABLE 1

Taxonomic list of vertebrates that were killed or collided with vehicles in the route 34 in $4 \mathrm{~km}$ stretch adjacent to Carara national park, Costa Rica

\begin{tabular}{|c|c|c|c|}
\hline Species/lowest taxon & Common name & Count & Status* \\
\hline \multicolumn{4}{|l|}{ Amphibian } \\
\hline Trachycephalus typhonius & Pepper Tree Frogwere & 2100 & $\mathrm{LC}$ \\
\hline Scinax elaeochrous & Narrow-headed Tree Frog & 1500 & $\mathrm{LC}$ \\
\hline Bufonidae (young) & Toad & 409 & \\
\hline Agalychnis callidryas & Leaf-eyed Leaf Frog & 255 & $\mathrm{LC}$ \\
\hline Unidentified & Frog & 69 & \\
\hline Rhinella marina & Cane Toad & 25 & $\mathrm{LC}$ \\
\hline Incilius coccifer & Dry Forest Toad & 20 & $\mathrm{LC}$ \\
\hline Rana sp. & Frog & 12 & \\
\hline Leptodactylus sp. & Foam Frog & 8 & \\
\hline Smilisca sp. & Tree Frog & 4 & \\
\hline Total & & 4402 & \\
\hline \multicolumn{4}{|l|}{ Reptiles } \\
\hline Serpentes & Snake & 65 & \\
\hline Ctenosaura similis & Spiny-tailed Iguana & 20 & $\mathrm{LC}$ \\
\hline Lacertilia & Lizard & 12 & \\
\hline Boa constrictor & Boa constrictor & 10 & NA \\
\hline Leptodeira sp. & Cat-eyed Snake & 10 & \\
\hline Kinosternon scorpioides & Scorpion Mud Turtle & 7 & $\mathrm{LR} / \mathrm{NT}$ \\
\hline Bothrops asper & Fer-de-lance Snake & 4 & NA \\
\hline Sibon sp. & Snail-eater Snake & 4 & \\
\hline Testudinae & Turtle & 4 & \\
\hline Rhinoclemmys pulcherrima & Painted Wood Turtle & 3 & NA \\
\hline Lampropeltis triangulum & Costa Rican Milk Snake & 3 & $\mathrm{LC}$ \\
\hline Leptodeira septentrionalis & Northern Cat-eyed Snake & 2 & NA \\
\hline Micrurus sp. & Coral Snake & 2 & \\
\hline Micrurus nigrocinctus & Coral Snake & 2 & $\mathrm{LC}$ \\
\hline Norops sp. & Anole Lizard & 2 & \\
\hline Micrurus alleni & Allen's Coral Snake & 1 & $\mathrm{LC}$ \\
\hline Leptodeira annulata & Annulated Cat-eyed Snake & 1 & $\mathrm{LC}$ \\
\hline Crocodylus acutus & American Crocodile & 1 & $\mathrm{~V}$ \\
\hline Drymobius margaritiferus & Speckled Racer Snake & 1 & NA \\
\hline
\end{tabular}


TABLE 1 (Continued)

\begin{tabular}{|c|c|c|c|}
\hline Species/lowest taxon & Common name & Count & Status* \\
\hline Geophis sp. & Earth Snake & 1 & NA \\
\hline Iguana iguana & Green Iguana & 1 & NA \\
\hline Kinosternon leucostomum & Turtle & 1 & NA \\
\hline Oxybelis sp. & Vine Snake & 1 & \\
\hline Pseustes poecilonotus & Bird Snake & 1 & NA \\
\hline Spilotes pullatus & Tiger Rat Snake & 1 & NA \\
\hline Total & & 160 & \\
\hline \multicolumn{4}{|l|}{ Mammals } \\
\hline Muridae & Mice and rats & 24 & \\
\hline Microchiroptera & Bat & 20 & \\
\hline Tamandua mexicana & Northern Tamandua & 16 & $\mathrm{LC}$ \\
\hline Nasua narica & White-nosed Coati & 5 & $\mathrm{LC}$ \\
\hline Didelphis marsupialis & Common Opossum & 5 & $\mathrm{LC}$ \\
\hline Procyon lotor & Northern Raccoon & 5 & $\mathrm{LC}$ \\
\hline Leopardus pardalis & Ocelot & 3 & $\mathrm{LC}$ \\
\hline Potos flavus & Kinkajou & 4 & $\mathrm{LC}$ \\
\hline Philander opossum & Gray Four-eyed Opossum & 2 & $\mathrm{LC}$ \\
\hline Cabassous centralis & Northern Naked-tailed Armadillo & 1 & DD \\
\hline Cebus capucinus & White-faced Capuchin & 1 & NA \\
\hline Conepatus semistriatus & Striped Hog-nose Skunk & 1 & $\mathrm{LC}$ \\
\hline Galictis vittata & Greater Grison & 1 & $\mathrm{LC}$ \\
\hline Unidentified & & 8 & \\
\hline Total & & 96 & \\
\hline \multicolumn{4}{|l|}{ Avian } \\
\hline Cathartidae & Vulture & 3 & \\
\hline Piranga rubra & Summer Tanager & 2 & $\mathrm{LC}$ \\
\hline Ramphocelus costaricensis & Cherrie's Tanager & 2 & $\mathrm{LC}$ \\
\hline Aramides cajanea & Gray-necked Wood-Rail & 1 & $\mathrm{LC}$ \\
\hline Caracara cheriway & Crested Carara & 1 & $\mathrm{LC}$ \\
\hline Lurocalis semitorquatus & Short-tailed Nighthawk & 1 & $\mathrm{LC}$ \\
\hline Nyctidromus albicollis & Common Pauraque & 1 & \\
\hline Phaethornis striigularis & Stripe-throated Hummingbird & 1 & $\mathrm{LC}$ \\
\hline Piaya cayana & Squirrel Cuckoo & 1 & $\mathrm{LC}$ \\
\hline Ramphastos ambiguus & Black-mandibled Toucan & 1 & NT \\
\hline Thraupis episcopus & Blue-gray Tanager & 1 & $\mathrm{LC}$ \\
\hline Threnetes ruckeri & Band-tailed Barbthroat & 1 & $\mathrm{LC}$ \\
\hline Thryophilus rufalbus & Rufous-and-white Wren & 1 & $\mathrm{LC}$ \\
\hline Trogon massena & Slaty-tailed Trogon & 1 & $\mathrm{LC}$ \\
\hline Unidentified & Bird & 17 & \\
\hline Total & & 35 & \\
\hline Undetermined & & 16 & \\
\hline
\end{tabular}

Conservation status as in IUCN; LR/NT = Lower Risk/Near Threatened; LC $=$ Least Concern, NA = Not Assessed, V= Vulnerable, DD = Data Deficient, NT = Near Threatened. 
Temporal variation: The estimated relative mortality per day (35 sampled days) in the $4 \mathrm{~km}$ segment was 125.4 amphibians, 4.6 reptiles, 2.7 mammals, 1 bird and 0.46 undetermined. In the case of the amphibians, there was a strong temporal pattern of mortality in which $99.5 \%$ of the death occurred between January and May (Fig. 2, 21 sampled days). Thus, the rate of amphibian mortality would be 140.9 roadkills per day if we consider only the number of sampled days during this period of the year.

The four most frequently killed species of amphibians showed well defined temporal peaks of road mortality. The relative mortality of the two bufonidae species (Rhinella mari$n a$ and Incilius coccifer) began to increase in December peaking in February and decreasing in April. A similar pattern was observed for Agalychnis callidryas, but with a sharp increase in December and a peak in January (Fig. 2). In contrast, mortality of Trachycephalus typhonius was constant through April and May, coinciding with the single mass mortality event of Scinax elaeochrous at the end of May (Fig. 2). An estimated 1500 individuals of $S$. elaeochrous were recorded on May 30, 2011 (Fig. 2). We also counted 241 individuals of $T$. typhonius on the same date and location.

Temporal variation in road mortality within the other vertebrate groups, were more variable than in amphibians. Nevertheless, generalized peaks appear to occur between November through January and April through May (Fig. $3)$. It is important to note that mortality patterns of reptiles are strongly influenced by the number of snakes counted. Snakes were more frequently killed during April and May (Fig. 3). Likewise, the increase in mammal mortality between April and May was strongly influenced by the Muridae (38.8 \%) and Microchiroptera $(36.4 \%)$. In general, mammals and birds were more often killed between November and January (Fig. 3).

Spatial variation: We found clear spatial aggregations of dead animals, especially amphibians, in some spots along the $4 \mathrm{~km}$ road segment during 35 regular sampling days (Fig. 1). Although all species of amphibians were found along the entire road segment, six blackspots (sensu Brockie, 2007) of mass mortality

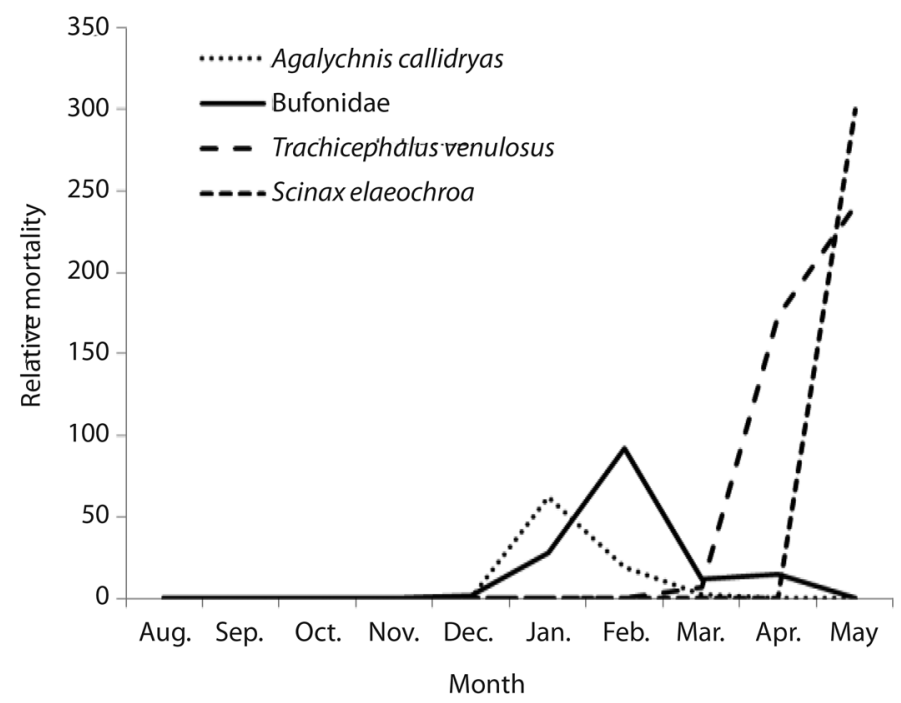

Fig. 2. Temporal variation of the relative road mortality for the most frequent species of amphibians killed along the 34 National Road that borders Carara National park. The family Bufonidae includes the species Incilius coccifer and Rhinella marina. 


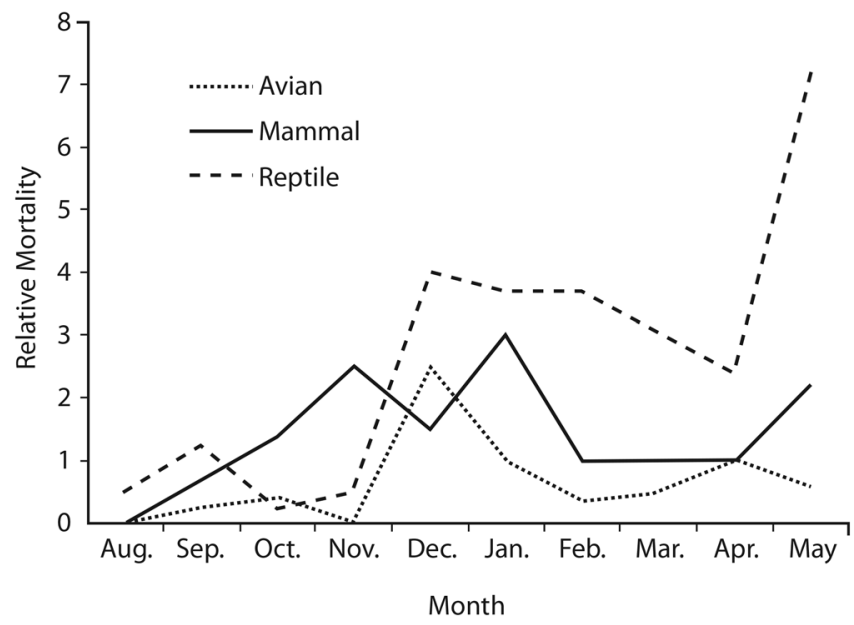

Fig. 3. Temporal variation of the relative road mortality for three taxonomic groups of vertebrates killed along the 34 National Road that borders Carara National park.

were identified (Fig. 4). Within the blackspots mortality rates ranged from 7.8 to 19.4 individuals per day. The first blackspot (from the upper North towards the Southwest limit) was dominated by two species of bufonidae Incilius coccifer and Rhinella marina (Fig. 4). The second aggregation was formed by three contiguous spots on a straight road segment and another further down on the curve of the road before the entrance to the park (Fig. 4). These four spatially aggregated blackspots were characterized by the greatest proportion of roadkills and primarily contained T. typhonius and $S$. elaeochrous. The latter species includes approximately 1500 individuals that were killed in a single day. The remaining blackspot was located near the Quebrada Bonita stream, close to a forest patch on the left side of the road (Fig. 4). The majority of the roadkills in this spot were frogs of the species A. callidryas. With the exception of $S$. elaeochrous, all the low to intermediate death densities along the road (Fig. 4) were dominated by the above mentioned species (Table 1).

The spatial distribution of dead reptiles showed a similar distribution of that found in amphibians (Fig. 4). The reptile densities ranged from 0.10 to 0.12 roadkills per day, in which $68 \%$ were snakes. Mammal kills were characterized by two aggregations and birds only by one, both groups with densities of 0.07 0.10 kills per day (Fig. 4).

Traffic volumes: Average number of vehicles increased sharply in December reaching a peak of almost 1200 vehicles per hour in January (Fig. 5). High volumes of vehicular traffic coincided generally with some peaks of roadkills (Fig. 2, Fig. 3 and Fig. 5). In addition, the number of vehicles on weekdays (Monday-Thursday) was significantly lower than that found on weekends (Wicoxon test, $\left.\mathrm{Z}_{10,33}=-4.385, \mathrm{P}<0.0001\right)$. Mean number of vehicles per hour on weekdays was 418.5 ( \pm 34.7) compared to 776.7 ( \pm 211.9$)$ during weekends. Light vehicles made $92.5 \%$ of the traffic volume. The volume of heavy vehicles (37.6 \pm 7.4 per hour) remained relatively constant regardless the day of the week. In contrast, the mean number of light vehicles almost doubled from $380( \pm 30.0)$ vehicles per hour on weekdays to $745.6( \pm 211.3)$ vehicles per hour on the weekends.

\section{DISCUSION}

Our results evidence the high rate of vertebrate roadkills in a $4 \mathrm{~km}$ segment of the road 
Amphibians

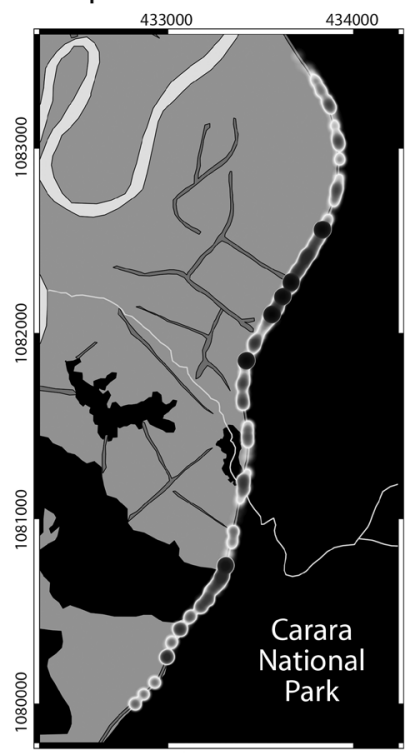

Legend

— Road 34 Quebrada Bonita

- Forest

$\square$ Tárcoles River

- Living fences

Amphibians all year

individuals per day $(n=35)$

0-0.13

0.13-0.17

$=0.17-0.23$

$0.23-0.27$

$0.27-0.33$

$0.33-0.42$

0.58-0.92

- $0.92-4.37$

- 4.37-19.17

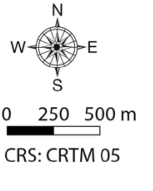

Mammals

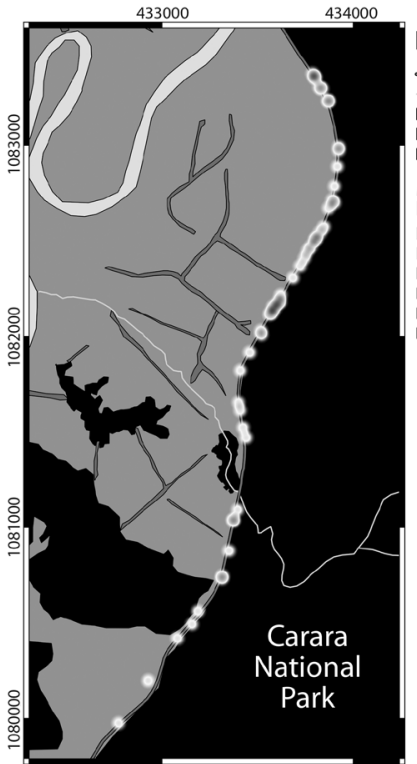

Legend

- Road 34

Quebrada Bonita

- Forest

Tárcoles River

Living fences

Mammals all year

Individuals per day $(n=35)$

0

$0-0.02$
$0.02-0.04$

$0.02-0.04$

$0.04-0.06$
$0.06-0.09$

- $0.09-0.11$

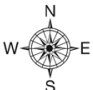

$0 \quad 250 \quad 500 \mathrm{~m}$

CRS: CRTM 05
Reptiles

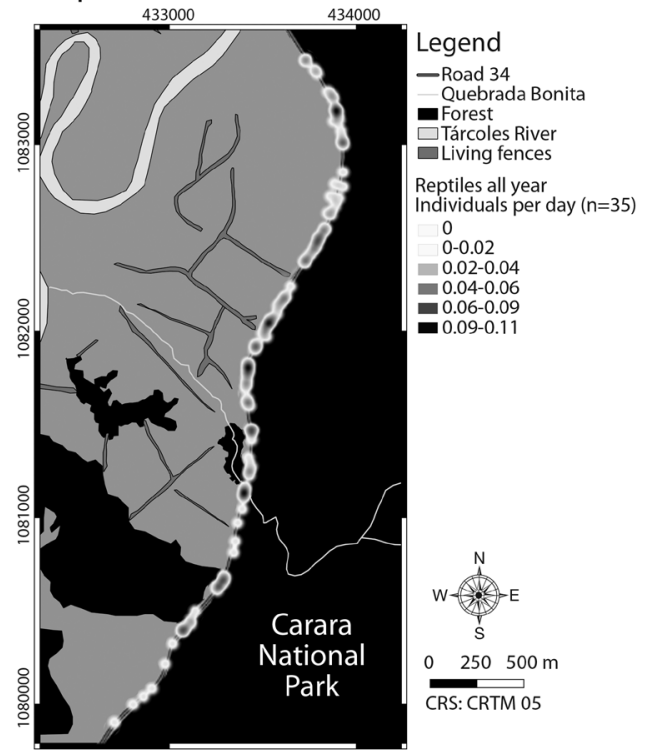

Birds

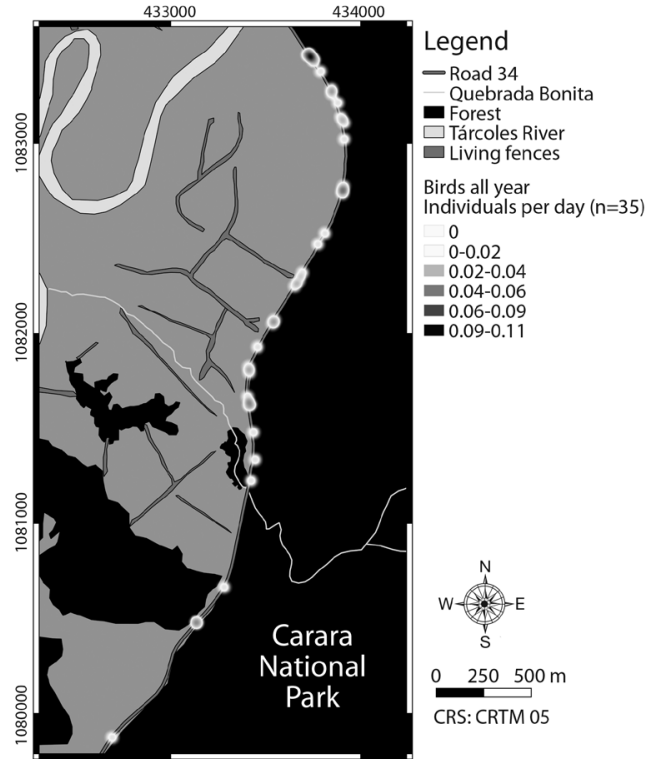

Fig. 4. Spatial distribution of vertebrate roadkills recorded along the 34 National Road bordering Carara National park. Differences in the density of amphibians, reptiles, mammals and birds are represented by the range of colors.

adjacent to Carara National Park. However, of the four taxonomic groups registered in this study, $93.5 \%$ of the kills were of amphibians. The high frequency of dead toads and frogs may be related to the seasonally high concentrations of these animals in temporary ponds and ditch drainages along the road, close to the forest edge of the park. Vegetation such as Calathea sp. and Heliconia sp., and grassy plants that predominate in some of these water 


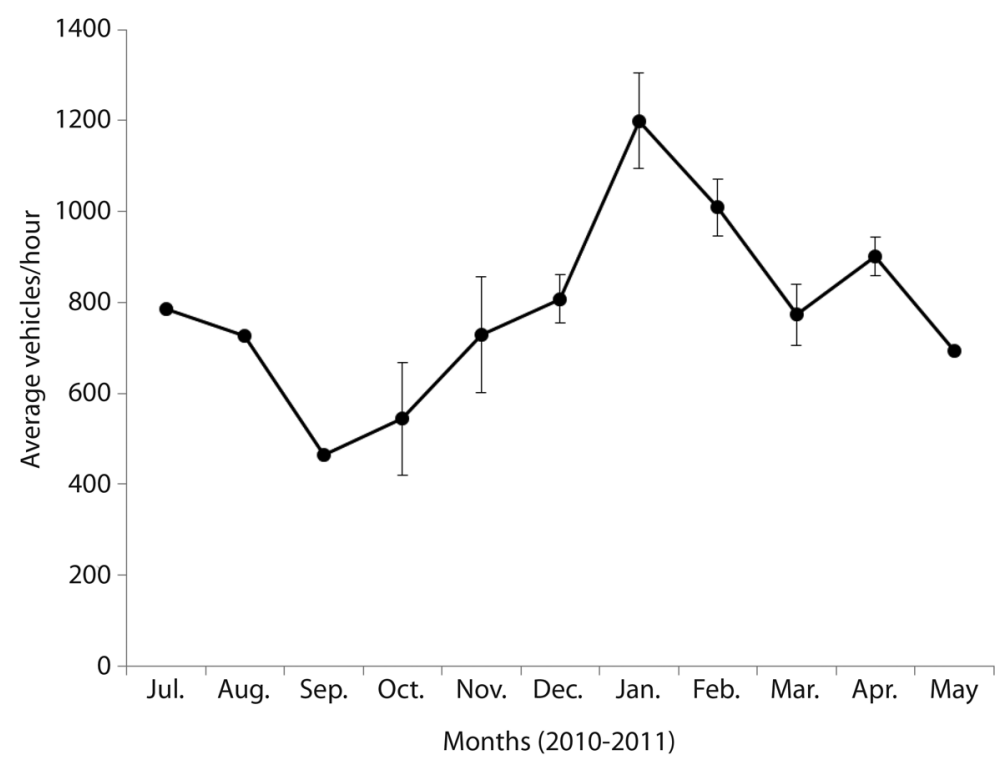

Fig. 5. Monthly variation of the average vehicles per hour circulating along the 34 National Road that limits with Carara National park. Vertical lines represent the range.

bodies, appear to provide suitable breeding sites for amphibians.

In Costa Rica most amphibians reproduce during the rainy season, but some species can opportunistically reproduce with the first rains prior to the advent of the season (Savage, 2002). Carara National Park receives about $2800 \mathrm{~mm}$ a year, mostly during the wet season (May through mid-November). In our study we found a peak in roadkills of $A$. callidryas in January and a peak for the two Bufonidae species in February, both during the dry season. It is likely that sporadic rains during these months have triggered early reproductive activity. Also, the proximity of a lagoon (Laguna Meandrica) and a stream (Quebrada Bonita) to the road could have facilitated opportunistic reproductive conditions. The peak of roadkills for T. typhonius and S. elaeochrous overlapped in May with the first heavy rains of the rainy season. However, the former showed an extended period of high mortality in comparison to the single mass event of the latter species. It is interesting to note that the mortality peaks of the species A. callidryas, T. typhonius and S. elaeochrous, all members of the Hylidae family, were somewhat separated in time and space. This suggests some segregation in the use of the temporary pools for reproduction. Strong seasonal patterns and temporal segregation in frog roadkill numbers have been previously reported. For example, Smith and Dodd (2003) found high mortality rates with separate temporal peaks for the five most commonly found frogs in Alachua County, Florida. The three species of Hylidae found in our study are primarily arboreal and descend to the temporary pools after heavy rains to call and mate. Hundreds to thousands of eggs are laid in the water or vegetation in an explosion of reproductive activity, after which the frogs return to their forest habitat (Savage, 2002). In contrast, the species $I$. coccifer and R. marina of the Bufonidae family prefer open areas and lay thousands of eggs in temporary or permanent pools (Savage, 2002). Thus, large aggregations of frogs and toads around available breeding grounds near the road, seem to be the cause of the mass mortality events of amphibians in this study. Previous studies have shown high rates -in the order of thousands- of amphibians killed in roads in close proximity to their 
spawning sites. For instance, a meta-analysis on road mortality rates of amphibians in Central Europe demonstrated that thousands of toads, frogs and newts are killed during migrations from their spawning grounds to other required habitats (Elzanowski et al., 2009).

We detected very low rates of amphibian mortality during the advanced rainy season (August-October). It could be that the use of a car during most of the rainy season and the use of a bicycle in the rest of the study could have influenced our counts. Nevertheless, we minimized the potential bias by driving slowly in a u-shape circuit. It is possible that some isolated amphibians could have been missed, but certainly not a mass mortality event. It is also possible that the extended rainy season with constant downpour rains decreased or diluted the reproductive events by these amphibian species. That is, because more breeding sites were available, the amphibians were much more spatially dispersed.

Spatiotemporal variation in reptile mortality generally matches the pattern found for amphibians. As stated before, snakes were the most frequently killed within this taxonomic group $(68.1 \%)$. Snakes dominated the peaks observed in December through February as well as the sharp increase in May. Unlike the presumed cause of amphibians mortality attributed to their aggregations and movements around bodies of water, the increased mortality of snakes during the same period is not clear. Reptiles might be attracted to asphalt roads because they seek warm surfaces for basking (review in Forman et al., 2003). However, this would not necessarily explain the localized blackspots in time and space. Another plausible explanation is a temporal dynamic relationship between amphibians as prey and snakes as predators. It has been proposed that prey distribution and their predictable resources (e.g. spawning sites) could influence that of predators (Flaxman \& Lou, 2009). In our study, some species of snakes like Leptodeira annulata and Drymobius margaritiferus are reported to feed primarily on frogs and toads (Savage, 2002; Guyer \& Donnelly, 2005). For example, species in the genus Leptodeira congregate near ponds during the breeding season of frogs and toads to eat adults or eggs (Savage, 2002). Determined and undetermined species of Leptodeira were the most common snakes in our study. Likewise, though less localized, is the relatively high frequency of Boa constrictor along the roadkill counts. In this case, it is possible that this species is attracted by the relative high number of live Spiny-tailed Iguana (Ctenosaura similis) and small (e.g. mice and rats) to medium size (e.g. opossums) mammals that are known to be important part of its diet (Savage, 2002; Guyer \& Donnelly, 2005).

Mammal roadkills increased in November reaching a peak in January. As with snakes, it is possible that some of the mammals killed were attracted by aggregations of prey. For example, European polecats (Mustela putorius) are frequently killed while seeking their main prey European rabbits (Oryctolagus cuniculus) in warrens distributed along roads (Barrientos \& Bolonio, 2009). In our study species of omnivores like raccoons and opossums could be attracted by mice, frogs or carrion in general (Reid, 1997; Wainwright, 2007) and get killed in the foraging process. In addition, some species of mammals may be killed while moving to other habitats. In our study half (8) of the Northern Tamanduas (Tamandua mexicana) and the four Kinkajous (Potos flavus) recorded in the surveys were killed in the peaks between November and January. This relatively high temporal mortality may be the result of dispersal activity since these two species are strongly arboreal, particularly the Kinkajou (Reid, 1997; Wainwright, 2007).

The explanation for the bird mortality peak in December is unclear. The main nesting peak takes place from April through June (Stiles \& Skutch, 1989), so it is possible that dispersing individuals following fledging accounted for the deaths. There is evidence that young, naïve individuals are more likely to get killed on roads than more experienced adults (Mumme, Schoech, Woolfenden, \& Fitzpatrick, 2000). However, we could not verify this as five out eight dead birds during December and January 
were so badly damaged that they could not be identified. Another explanation for the increase of bird kills is the high traffic volumes between December and January, as bird mortality rates may increase with traffic volume (Forman et al. 2003). Another potential factor is that some species of birds are attracted to roads because of increased food availability. Carrion feeders like vultures (Catharttidae) and Caracaras (Falconidae) were found dead on the road, presumably killed by traffic while feeding. In one occasion a Crested Caracara (Caracara cheriway) was almost hit by a car while trying to carry away a flat armadillo carcass (J.E. Arévalo, pers. obs.). We also found species such as tanagers (Ramphocelus costaricensis and Thraupis episcopus) and nighthawks (Lurocalis semitorquatus and Nyctidromus albicollis) that actively move or forage near forest edges. Relative to other vertebrates, birds were the most infrequent roadkills. Arévalo and Newhard (2011) found that bird density and species richness decrease with road proximity in Carara National Park, potentially explaining the observed low bird mortality.

Costa Rica's national conservation system currently provides different levels of protection for $26 \%$ of the country. In addition, forest cover has increased considerably over the last 30 years, mainly due to the recent shift from agriculture to a service-based economy (Chase, Lee, Schulze, \& Anderson, 1998; Gouvea, 2004) and forest conservation incentives through the Environmental Service Payments (Pagiola, 2008). However, there is a negative side to these conservation trends. The rapid development of tourism has led to urbanization and an expanding road network with concomitant increases in traffic in and around protected areas. The case of Carara National Park clearly demonstrates how the current traffic volumes are killing significant numbers of animals, although we do not know what impacts these roadkills are having on the long-term demographics of the affected species. Nonetheless, studies have demonstrated negative population-level effects on vertebrate species due to road mortality (review in Fahrig \& Rytwinsky, 2009).

The mortality of amphibians observed in our study is of great conservation concern because one of the most affected groups are individuals that are aggregating for reproduction, leading to mass mortality of females, males and juveniles. Limitations on the dispersal of juveniles can greatly affect population recruitment and consequently increase the probability of local population extinction (Cushman, 2006). Another conservation concern is mortality of medium size carnivores. We found three dead Ocelots (Leopardus pardalis) in our counts, and Margays (L. wiedii) and a Jaguarundi (Puma yagouaroundi) in previous preliminary surveys (unpublished data). These species are considered under the risk of extinction in Costa Rica (www.inbio.ac.cr), where they are mostly restricted to larger protected areas. Slow reproduction, hunting pressure and habitat loss already compromise the viability and persistence of some local populations (Wainwright, 2007). Thus, the additional loss to car collisions of these endangered animals - even though the absolute numbers are low - may lead to population decline and local extinction (Fahrig \& Rytwinsky, 2009; Rytwinsky \& Fahrig, 2012).

Since Carara National Park aims to conserve the largest highly biodiverse wet-todry forest remnant in the country, mitigation actions must be considered and implemented to minimize traffic-related wildlife mortality. Several mechanisms that prevent wildlife road mortality while maintaining safe animal movements across roads have been proposed (Forman et al., 2003). The most commonly implemented mechanisms in the United States include warning signs, mirrors and reflectors, public relations and warning whistles. However, structural changes such as wildlife fencing and the construction of overpasses and underpasses were reported to be the most effective mechanisms for reducing mortality and population fragmentation (Forman et al., 2003). For instance, surveys evaluating fencing highway segments recorded an $80 \%$ reduction 
in ungulate mortality (Clevenger, Chruszcz, \& Gunson, 2001) in Banff National Park in Canada, and a $93.5 \%$ reduction in vertebrate mortality in Florida, United States (excluding hylid tree frogs) (Dodd, Barichivich, \& Smith, 2004). Even when fences are absent, animals can use culverts that are not specifically designed as wildlife underpasses. For example, Torres (2011) observed 277 events of vertebrates crossing culverts along the Inter-American Highway bisecting Guanacaste National Park in Costa Rica, $80 \%$ of which were medium to large mammals.

Specific mitigation measures in Carara National Park would be most expeditiously achieved through improved planning. This must be done through a joint approach between park administrators, the Ministry of Public Transportation (MOPT), local community associations and wildlife management experts. As short-term mitigation measures we recommend the implementation of speed limits for the circulating vehicles, the installation of visible warning signs (recently implemented) and a campaign to educate motorists about how to prevent wildlife collisions. Low speed limits allow more time for drivers react to fast moving animals (Van Langevelde \& Jaarsma, 2004). The measures suggested above, however, would not be effective to reduce amphibian mass roadkills because of their small size and high densities on the road. Thus, other parallel measures such as barriers with underpasses near known blackspots should also be considered (see Rytwinsky \& Fahrig, 2012). We propose the retrofitting of the already existent culverts as underpasses for small, medium and large bodied animals. There are two contiguous $3 \times 2.5 \mathrm{~m}$ underpasses in the Quebrada Bonita that allow some animal crossing (J.E. Arévalo, pers. obs.). Other two $1.5 \mathrm{~m}$ in diameter could serve as underpasses for frogs and small mammals. The other six small size culverts would need to be replaced by other of at least $1.5 \mathrm{~m}$ in diameter. In addition, barriers near the underpasses need to be built in order to direct animal movements towards the culverts. An additional large underpass similar to the one in Quebrada
Bonita would be ideal near the Laguna Meandrica trail entrance. Finally, we propose aerial bridges between the park and a relatively large forest fragment in the Southwest side of the study area. The bridges would facilitate the crossing of arboreal mammals.

In summary, the frequency at which different vertebrates are killed on the road adjacent to Carara National Park strongly depends on traffic volumes and the life history of the species. Amphibians, particularly frogs and toads, which usually reproduce during mass events, do not avoid roads and are slow to move out of the way of approaching traffic. These conditions make amphibians especially vulnerable to the negative effects of roads (Fahrig \& Rytwinski, 2009; Rytwinsky \& Fahrig, 2012). Our study shows high levels of frog and toad mortality during a short period of time and in highly localized spots. Trophic relationships among vertebrate groups and animal dispersal processes could also exacerbate the incidence of roadkills. For example, highly mobile species such as predators and scavengers with wide home ranges and that do not avoid roads are particularly susceptible to be killed by cars (Fahrig \& Rytwinski, 2009; Rytwinsky \& Fahrig, 2012). Thus, any potential mitigation measure needs to take into account the behavior and life histories of the species that are most frequently killed on the road.

The numbers of amphibians, small birds and mammals reported in this study are probably underestimates due to failure to detect dead small animals and fast carcass removal by scavengers. In addition, medium and large size animals can be badly injured by collision but move towards the inner forest and die. For instance, park rangers rescued a WhiteThroated Capuchin Monkey (Cebus capucinus) after being badly injured by a car collision (W. Honda pers. obs.). Time intervals for the conducted surveys could have also influenced both spatial densities of the different groups (Santos et al., 2015; Costa, Ascensão, \& Bager, 2015).

Since traffic volumes increase during the weekends as demonstrated in our study, 
it is likely that roadkills are more likely to increase with road usage.

The Costa Rican road network currently comprises $35820 \mathrm{~km}$ (over $8000 \mathrm{~km}$ of asphalt roads) and is rapidly increasing with ongoing and future planning development (CONAVI 2011, National Council for Road Network Maintenance). In addition, increasing volume of traffic may increase the probability of animal collisions with cars. Consequently, many protected areas are likely to be directly or indirectly affected if measures are not implemented to mitigate the negative effects of roads at the local and landscape level. Specific legislation must be enacted to ensure the viability of wildlife populations under the protection goals of the National Conservation System.

\section{ACKNOWLEDGMENTS}

We are grateful to Richard Ladle for reviewing and commenting on our manuscript. We also thank the local tourist guide association (ASOGUIPACE) and park rangers for informing us about roadkills locations and general support during surveys. Students of School for Field Studies helped counting vehicles, Emily Blau and Celia Mason helped with the formatting of the article. The authors gratefully acknowledge the key financial and logistical support provided by the School for Field Studies.

\section{RESUMEN}

Variación espacio-temporal de atropellos de vertebrados muestra eventos de mortalidad masiva de anfibios en una carretera altamente transitada adyacente a un parque nacional, Costa Rica. Las carreteras tienen impactos perjudiciales en las poblaciones de vida silvestre en todo el mundo. Específicamente, los caminos representan amenazas directas e indirectas a la vida silvestre limitando los movimientos de dispersión, o debido a la mortalidad por atropellos por vehículos. La tasa de mortalidad de la fauna varía tanto en el tiempo como en el espacio, dependiendo de la composición del paisaje y del tipo y uso de la infraestructura vial. El objetivo de este estudio fue investigar la variación espaciotemporal de la mortalidad de vertebrados en un tramo de $4 \mathrm{~km}$ de la carretera nacional 34, adyacente al Parque Nacional Carara,
Costa Rica. Llevamos a cabo 81 censos de vertebrados atropellados utilizando un vehículo y una bicicleta entre junio 2010 y mayo 2011, georreferenciamos las ubicaciones de los cuerpos y los identificamos al nivel taxonómico más bajo posible. Registramos un total de 4709 animales muertos por carretera de al menos 58 especies de vertebrados durante todo el estudio. Los anfibios representaron el $93.5 \%$ de todos los vertebrados y mostraron una fuerte variación espaciotemporal en eventos de mortalidad masiva. Los reptiles, especialmente las serpientes, fueron el segundo taxón más afectado seguido por los mamíferos y las aves. La mortalidad relativa por día en el segmento de $4 \mathrm{~km}$ fue de 125.4 anfibios, 4.6 reptiles, 2.7 mamíferos, 1 ave y 0.46 indeterminado. La proximidad de la carretera al límite del parque, los volúmenes de tránsito y la falta de cumplimiento de los límites de velocidad pueden influir en la alta tasa de mortalidad registrada. Sugerimos la reducción en los límites de velocidad, la señalización de cruce de vida silvestre y la readecuación de las alcantarillas existentes como pasos para los animales para minimizar la mortalidad de los vertebrados en la carretera adyacente al Parque Nacional Carara.

Palabras clave: amenaza de extinción, Áreas de conservación, bosque tropical, colisión de animales, mortalidad masiva de anfibios.

\section{REFERENCES}

Alvez da Rosa, C., \& Bager, A. (2012). Seasonality and habitat types affect roadkill of neotropical birds. Journal of Environmental Management, 97, 1-5.

Arévalo, J. E., \& Newhard, K. (2011). Traffic Noise affects forest bird species in a protected tropical forest. Revista de Biología Tropical, 59, 969-980.

Ashley, E. P., \& Robinson, J. T. (1996). Road mortality of amphibians, reptiles and other wildlife on the Long Point Causeway, Lake Erie, Ontario. Canadian Field Naturalist, 110, 404-412.

Barrientos, R., \& Bolonio, L. (2009). The presence of rabbits adjacent to roads increases polecat road Mortality. Biodiversity and Conservation, 18, 405-418.

Barthelmess, E. L., \& Brooks, M. S. (2010). The influence of body-size and diet on road-kill trends in mammals. Biodiversity and Conservation, 19, 1611-1629.

Bissonette, J. A. (2002). Scaling roads and wildlife: the Cinderella principle. Zeitschrift fur Jagdwissenschaft, 48, 208-214.

Brockie, R. (2007). Notes on New Zealand mammals 4. Animal road-kill "blackspots". New Zealand Journal of Zoology, 34, 311-316.

Cáceres, N. C., Hannibal, W., Freitas, D. R., Silva, E. L., Roman, C., \& Casella, J. (2010). Mammal occurrence 
and roadkill in two adjacent ecoregions (Atlantic Forest and Cerrado) in south-western Brazil. ZOOLOGIA, 5, 709-717.

Chase, L. C., Lee, D. R., Schulze, W. D., \& Anderson, D. J. (1998). Ecotourism demand and differential pricing of National park access in Costa Rica. Land Economics, 74, 446482 .

Clarke, G. P., White, P. L. C., \& Harris, S. (1998). Effects of roads on badger Meles meles populations in southwest England. Biological Conservation, 86, 117-124.

Clevenger, A. P., Chruszcz, B., \& Gunson, K. E. (2001). Highway mitigation fencing reduces wildlife-vehicle collisions. Wildlife Society Bulletin, 29, 646-653.

Clevenger, A. P., Chruszcz, B., \& Gunson, K. E. (2003). Spatial patterns and factors influencing small vertebrate fauna road-killed aggregations. Biological Conservation, 109, 15-26.

Coelho, I. P., Kindel, A., \& Coelho, A. V. P. (2008). Roadkills of vertebrate species on two highways through the Atlantic Forest Biosphere Reserve, southern Brazil. European Journal of Wildlife Research, 54, 689-699.

Coffin, A. W. (2007). From roadkill to road ecology: A review of the ecological effects of roads. Journal of Transport Geography, 15, 396-406.

Colchero, F., Conde, D. A., Manterola, C., Chávez, C., Rivera, A., \& Ceballos, G. (2010). Jaguars on the move: modeling movement to mitigate fragmentation from road expansion in the Mayan Forest. Animal Conservation, 14, 158-166.

Costa, A. S., Ascensão, F., \& Bager, A. (2015). Mixed sampling protocols improve the cost-effectiveness of roadkill Surveys. Biodiversity and Conservation, 24, 2953-2965.

Cushman, S. A. (2006). Effects of habitat loss and fragmentation on amphibians: A review and prospectus. Biological Conservation, 128, 231-240.

Develey, P. F., \& Stouffer, P. C. (2001). Effects of roads on movements by understory birds in mixed-species flocks in central Amazonian Brazil. Conservation Biology, 15, 1416-1422.

Dodd Jr., C. K., Barichivich, W. J., \& Smith, L. L. (2004). Effectiveness of a barrier wall and culverts in reducing wildlife mortality on a heavily traveled highway in Florida. Biological Conservation, 118, 619-631.

Elzanowski, A., Ciesiolkiewicz, J., Kaczor, M., Radwanska, J., \& Urban, R. (2009). Amphibian road mortality in Europe: a meta-analysis with new data from Poland. European Journal of Wildlife Research, $55,33-43$.
Erickson, W. P., Johnson, G. D., \& Young, D. P. Jr. (2005). A summary and comparison of bird mortality from anthropogenic causes with an emphasis on collisions. USDA Forest Service Gen Tech Rep. PSWGTR-191, 1029-1042.

Fahrig, L., \& Rytwinski, T. (2009). Effects of roads on animal abundance: an empirical review and synthesis. Ecology and Society, 14(1), 21.

Flaxman, S. M., \& Lou, Y. (2009). Tracking prey their prey resource? Mechanisms of movements and optimal habitat selection by predators. Journal of Theoretical Biology, 256, 187-200.

Ford, A. T., \& Fahrig, L. (2007). Diet and body size of North American mammal road mortality. Transportation Research Part D, 12, 498-505.

Forman, R. T. T., \& Alexander L. E. (1998). Roads and their major ecological effects. Annual Review of Ecology and Systematics, 29, 207-231.

Forman, R. T. T., Sperling, D., Bissonette, J., Clevenger, A., Cutshall, C., Dale, V., Fahrig, F., France, R., Goldman, C., Heanue, K., Jones, J., Swanson, F., Turrentine, T., \& Winter, T. (2003). Road Ecology: Science and solutions. Washington D.C. USA: Island Press.

Glista, D. J., DeVault, L. E., \& DeWoody, J. A. (2008). Vertebrate road mortality predominantly impacts amphibians. Herpetological Conservation \& Biology, 3, 77-87.

González-Gallina, A., Benítez-Badillo, G., Rojas-Soto, O. R., \& Hidalgo-Mihart, M. G. (2013). The small, the forgotten and the dead: highway impact on vertebrates and its implications for mitigation strategies. Biodiversity and Conservation, 22, 325-342.

Gouvea, R. (2004). Managing the ecotourism industry in Latin America: challenges and opportunities. Problems and Perspectives, 2, 1-9.

Groot Bruinderink, G. W. T. A., \& Hazebroek, E. (1996). Ungulate traffic collisions in Europe. Conservation Biology, 10, 1059-1067.

Guinard, E., Julliard, R., \& Barbraud, C. (2012). Motorways and bird traffic casualties: Carcasses surveys and scavenging bias. Biological Conservation, 147, 40-51.

Guyer, C., \& Donnelly, M. A. (2005). Amphibians and reptiles of La Selva, Costa Rica, and the Caribbean Slope. London, England: University of California Press.

Hodson, N. L., \& Snow, D. W. (1965). The road death enquiry, 1960-1961. Bird Study, 12, 90-98.

Holdridge, L. R. (1966). The life zone system. Adansonia, 6, 199-203 
Laurance, W. F., Goosem, M., \& Laurance, G. W. (2009). Impacts of roads and linear clearings on tropical forest. Trends in Ecology \& Evolution, 24, 659-669.

Langen, T. A., Machniak, A., Crowe, E. K., Mangan, C., Marker, D. F., Liddle, N., \& Roden, B. (2007). Methodologies for surveying herpetophauna mortality on rural highways. Journal of Wildlife Management, 71, 1361-1368.

Long, E. S., Diefenbach, D. R., Wallingford, D. B., \& Rosenberry, C. S. (2010). Influence of roads, rivers and mountains on natal dispersal of White-Tailed Deer. Journal of Wildlife Management, $74,1242-1249$.

Mader, H. J., Schell, C., \& Kornacker, P. (1990). Linear barriers to arthropod movements in the landscape. Biological Conservation, 54, 209-222.

Monge-Nágera, J. (1996). Vertebrate mortality on tropical Highways: The Costa Rican case. Vida Silvestre Neotropical, 5, 154-156.

Mumme, R. L., Schoech, S. J., Woolfenden, G. E., \& Fitzpatrick, J. W. (2000). Life and death in the fast lane: Demographic consequences of road mortality in the Florida Scrub-Jay Conservation Biology, $14,501-512$.

Pagiola, S. (2008). Payments for environmental services in Costa Rica. Ecological Economics, 65, 712-724.

Pomareda, E. (2012). Una amenaza real de atropellos de animales silvestres. http://www.semanario.ucr.ac.cr/ index.php/opinion/7677--una-amenaza-real-atropello-de-animales-silvestres.html

Reid, F. A. (1997). A field guide to the mammals of Central America and Southeast Mexico. New York, USA: Oxford University Press.

Rodríguez-Castro, K. G., Ciocheti, G., Ribeiro, J. W., Ribeiro M. C., \& Galetti, P. M. Jr. (2017). Using DNA barcode to relate landscape attributes to small vertebrate roadkill. Biodiversity and Conservation, $26,1161-1178$

Rojas-Chacón, E. (2011). Atropello de vertebrados en una carretera secundaria en Costa Rica. Cuadernos de Investigación UNED, 3, 81-84.

Rytwinsky, T. \& Fahrig, L. (2012). Do species life history traits explain population responses to roads? A metaanalysis. Biological Conservation, 147, 87-98.
Santos, S. M., Tiago-Marques, J., e Lourenço, A., Medinas, D., Barbosa, A. M., Beja, P., \& Mira, A. (2015). Sampling effects on the identification of roadkill hotspots: Implications for survey design. Journal of Environmental Management, 162, 87-95.

Savage, J. M. (2002). The amphibians and reptiles of Costa Rica. Chicago, USA: The University of Chicago Press.

Silverman, B. W. (1986). Density estimation for statistics and data analysis. New York, USA: Chapman and Hall.

Slater, F. (2002). An assessment of wildlife road casualtiesthe potential discrepancy between numbers counted and numbers killed. Web Ecology, 3, 33-42.

Smith, L. L., \& Dodd, C. K. (2003). Wildlife mortality on U.S. Highway 441 across Paynes Prairie, Alachua County, Florida. Florida Scientist, 66, 128-140.

Stiles, F. G., \& Skutch, A. F. (1989). A Guide to the Birds of Costa Rica. Ithaca, New York, USA: Cornell University.

Taylor, B. D., \& Goldingay, R. L. (2010). Road and wildlife: impacts, mitigation and implications for wildlife management in Australia. Wildlife Research, 37, 320-331.

Teixeira, F. Z., Coelho, A. V. P., Esperandio, I. B., \& Kindel, A. (2013). Vertebrate road mortality estimates: effects of sampling methods and carcass removal. Biological Conservation Journal, 157, 317-323.

Torres, M. L. (2011). Funcionalidad de estructuras subterráneas como pasos de fauna en la carretera Interamericana Norte que cruza el Area de Conservación Guanacaste, Costa Rica (Tesis de Maestría). CATIE, Costa Rica.

Van der Ree, R., Smith, D. J., \& Grilo, C. (2015). The ecological effects of linear infrastructure and traffic: challenges and opportunities of rapid global growth. In R. Van der Reed, D. J. Smith \& C. Grilo (Eds.), The handbook of road ecology (pp. 1-9). U.K: Wiley Blackwell.

Van Langevelde, F., \& Jaarsma, C. F. (2004). Using traffic flow theory to model traffic mortality in mammals. Land Ecology, 19, 895-907.

Wainwright, M. (2007). The mammals of Costa Rica. Ithaca, USA: Wiley Blackwell. 